\title{
Chemical sterilization of culture medium for in vitro multiplication of Cochlospermum regium
}

\section{Natália Helena Gavilan ${ }^{1,2}$ Fernanda Cardoso Furlan ${ }^{1}$ Alex Zichner Zorz ${ }^{1}$ Leandro Silva de Oliveira ${ }^{3}$ (-) Wellington Ferreira Campos $^{4}$ (-) Gilvano Ebling Brondani ${ }^{1,5^{*}}$ (?)}

\author{
${ }^{1}$ Universidade Federal de Mato Grosso (UFMT), Cuiabá, MT, Brasil. \\ ${ }^{2}$ Universidade Estadual Paulista (UNESP), Botucatu, SP, Brasil. \\ ${ }^{3}$ Universidade Federal de Minas Gerais (UFMG), Montes Claros, MG, Brasil. \\ ${ }^{4}$ Universidade Federal dos Vales do Jequitinhonha e Mucuri (UFVJM), Unaí, MG, Brasil. \\ ${ }_{5}^{5}$ Departamento de Ciências Florestais, Universidade Federal de Lavras (UFLA), 37200-000, Lavras, MG, Brasil. E-mail: gebrondani@gmail.com. \\ ${ }^{*}$ Corresponding author.
}

\begin{abstract}
Cochlospermum regium roots are used in popular medicine and its extract has diverse phytochemical molecules some with antimicrobial activity, consequently exposing this specie to genetic erosion risks. Thus, the objective of this study was to develop an in vitro multiplication protocol using chemical sterilization of culture medium. Therefore, explants obtained from apical buds of C. regium seedlings

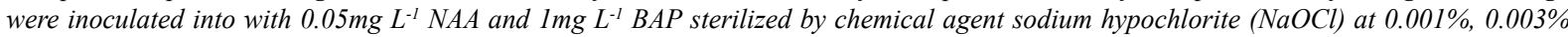
and $0.005 \%$ of active chlorine (Cl). Autoclaved culture medium was used as control. Result showed that the contamination by bacterial at 91 days of cultivation was significantly $(P<0.05)$ controlled by autoclaving, $0.001 \%$ and $0.005 \%$ Cl. Moreover, the callus induction in the culture medium with $0.001 \%$ and $0.005 \% \mathrm{Cl}$ was, respectively, $30 \%$ and $20 \%$ major than autoclaving sterilization. There was not significant (P<0.05) in the percentage of shoot induction among the sterilization preparations methods, and 65\% of the explants survived in the presence of culture medium with $0.005 \% \mathrm{Cl}$. Histological analyses indicated that the Cl did not have any deleterious effects on morphogenic events. These results indicated that the chemical sterilization using $0.001 \%-0.005 \% \mathrm{Cl}$ controlled the fungal and bacterial multiplication in the culture medium and no affected the C. regium explants development, becoming it an alternative to autoclaving method.

Key words: autoclaving, cerrado biome, active chlorine, in vitro cultivation.
\end{abstract}

Esterilização química do meio de cultura para a multiplicação in vitro de Cochlospermum regium

RESUMO: As raizes de Cochlospermum regium são usadas na medicina popular, pois seu extrato apresenta diversas moléculas fitoquímicas, algumas com atividade antimicrobiana, que, consequentemente, expõe esta espécie ao risco de erosão genética. Assim, o objetivo deste estudo foi elaborar um protocolo de multiplicação in vitro para explantes de C. regium usando esterilização química do meio de cultura. Gemas apicais obtidas de plântulas de C. regium germinadas in vitro foram inoculadas em meio de cultivo MS suplementado com 0 ,05mg $L^{-1}$ de ANA e $\operatorname{lmg~} \mathrm{L}^{-1}$ de BAP e esterilizado pela adição do agente químico hipoclorito de sódio (NaOCl) nas concentrações de cloro ativo de 0,001\%, $0,003 \%$ e 0,005\%. O meio autoclavado foi utilizado como controle. Os resultados mostraram que a contaminação por bactérias aos 91 dias de cultivo foi significativamente $(P<0,05)$ controlada pela autoclavagem, 0,001\% e 0,005\% de cloro ativo. Além disso, a indução de calos no meio de cultura com 0,001\% e 0,005\% de cloro ativo foi, respectivamente, 30\% e 20\% maior do que na esterilização por autoclavagem. Não houve diferença significativa $(P<0,05)$ da porcentagem de indução de brotos entre os métodos de esterilização e $65 \%$ dos explantes sobreviveram na presença de 0,005\% de cloro ativo. Análises histológicas indicaram que o cloro ativo não afetou os eventos morfogênicos. Os resultados indicaram que a esterilização química por meio do uso de 0,001\% - 0,005\% de cloro ativo auxiliou no controle da proliferação de bactérias e fungos no meio de cultura e não afetou o desenvolvimento dos explantes de C. regium, tornando-a uma alternativa em relação a autoclavagem. Palavras-chave: autoclavagem, bioma cerrado, cloro ativo, cultivo in vitro.

\section{INTRODUCTION}

The Cerrado is the second biggest Brazilian biome with 4,400 endemic plant species. This biome has been lost large area and so it is considered an important biodiversity hotspots designated for priority conservation (MYERS et al., 2000). Several plants from Cerrado are known as source of medical compounds and food interests (CARAMORI et al., 2004). Cochlospermum regium (Schrank) Pilger, popularly known as 'algodãozinho' or 'algodãozinho do cerrado', is a medicinal species belonging to Bixaceae family and is commonly found in Cerrado (SÓLON et al., 2009; BATISTA et al., 
2014). Roots and barks from C. regium plants are used in popular medicine to treat female reproductive system infections, intestinal inflammation, rheumatoid arthritis, ulcers, leucorrhoea, cancer and gastritis (TRESVENZOL et al., 2006; SOUZA \& FELFILLI, 2006; MOREIRA \& GUARIM-NETO, 2009; SÓLON et al., 2009; MELO et al., 2011; BATISTA et al., 2014). Phytochemical analyses of C. regium extract indicated the presence of essential oils, flavonoids, saponins, triacylbenzenes, tannins, phenol derivatives, steroidal triterpenes and gallic acid derivatives, providing support to justify its use as popular phytotherapic (BRUM et al., 1997; SÓLON et al., 2012). Moreover, essential oils and hydroalcoholic extracts of $C$. regium roots showed antimicrobial activity against Staphylococcus aureus, Pseudomonas aeruginosa and Salmonella typhimurium (BRUM et al., 1997; SÓLON et al., 2009; SÓLON et al., 2012; INÁCIO et al., 2014).

The use in an extractive way of $C$. regium roots for phytotherapeutic preparations, the destruction of its habitat and the lack agronomic studies that enable its large-scale cultivation exposes this specie to genetic erosion risks and has placed it on the priority list of native medicinal species for ex situ conservation (CAMILLO et al., 2009; INÁCIO et al., 2010). Thus, tissue culture, through the technique of micropropagation, becomes an alternative for the propagation and conservation. Even though advantages of micropropagation, some problems persist and do not meet commercial interests, especially those associated with the high costs of implementing and maintaining the technique, high energy consumption and time required preparing material of culture medium (MACEK et al., 1995; RIBEIRO et al., 2011; BRONDANI et al., 2013).

Autoclaving is an energetically expensive operation but is the most commonly sterilization method used in the laboratory. Chemical sterilization of culture medium with sodium hypochlorite $(\mathrm{NaOCl})$ is an alternative method for asepsis of lower cost that has been used for in vitro culture of several species, such as Sequoia sempervirens (RIBEIRO et al., 2011), Chrysantemum (DEEIN et al., 2013), Eucalyptus benthamii (BRONDANI et al., 2013), Hyptis leucochepala and H. platanifolia (NEPOMUCENO et al., 2014). Nevertheless, the necessary conditions for the active chlorine not to cause damage to the growth and development of $C$. regium tissues plant are not established. Therefore, the objective of this study was to develop an in vitro multiplication protocol of $C$. regium using chemical sterilization of culture medium.

\section{MATERIALS AND METHODS}

Seeds of $C$. regium were randomly collected between September and October of 2014 from mature fruits of 28 plants located in Cerrado area in the National Park of Chapada dos Guimarães, 'Chapada dos Guimarães', Mato Grosso, Brazil.

Seeds were washed with distilled and autoclaved water, and subsequently were immersed in sodium hypochlorite solution (i.e., $\mathrm{NaOCl}, 2.0-2.5 \%$ of active chlorine) for 20 minutes. After, triple wash with distilled and autoclaved water was performed, and the seeds were in vitro inoculated in MS culture medium (MURASHIGE \& SKOOG, 1962) for germination and growth. After 40 days, explants were obtained from apical buds of $C$. regium seedlings and inoculated into test tubes $(2 \times 10 \mathrm{~cm})$ containing $5 \mathrm{~mL}$ of MS culture medium supplemented with $0.05 \mathrm{mg} \mathrm{L}^{-1}$ of $\alpha$-naphthaleneacetic acid (NAA) and $1 \mathrm{mg} \mathrm{L}^{-1}$ of 6-benzylaminopurine (BAP).

Culture medium was prepared with distilled water, adding $6 \mathrm{~g} \mathrm{~L}^{-1}$ of agar and $30 \mathrm{~g} \mathrm{~L}^{-1}$ of sucrose and the $\mathrm{pH}$ value was adjusted to 5.8 with $\mathrm{HCl}(0.1 \mathrm{M})$ or $\mathrm{NaOH}(0.1 \mathrm{M})$. The culture medium was sterilized by addition of the chemical agent sodium hypochlorite $(\mathrm{NaOCl})$ in the concentrations of active chlorine $(\mathrm{Cl})$ of $0.001 \%, 0.003 \%$ and $0.005 \%$. Autoclaved culture medium was used as control, and was performed at $121^{\circ} \mathrm{C}\left(\sim 1 \mathrm{kgf} \mathrm{cm}^{-2}\right)$ for 20 minutes.

The first subculture occurred at 28 days, totaling 4 subcultures (28, 49, 70 and 91 days). At each subculture, the explants were transferred to the same MS culture medium as previously described. The procedure of manipulation of the explants was carried out in laminar flow chamber under aseptic conditions. The explants were grown in a growth room with controlled temperature at $25^{\circ} \mathrm{C} \pm 2{ }^{\circ} \mathrm{C}$, 16 hours of photoperiod $\left(32 \mu \mathrm{mol} \mathrm{m} \mathrm{m}^{-2} \mathrm{~s}^{-1}\right)$. During the cultivation time (91 days) each explant was evaluated about the percentage of fungal and bacterial contamination, callus induction, number of shoots, oxidation and survival.

To histological analysis, callus samples of $C$. regium were fixed in formaldehyde and modified glutaraldehyde ( $1 \%$ glutaraldehyde, $4 \%$ paraformaldehyde in sodium phosphate buffer $-0.1 \mathrm{M}$ $\mathrm{NaH}_{2} \mathrm{PO}_{4} \cdot \mathrm{H}_{2} \mathrm{O}$ at $\mathrm{pH}$ 7.2) (KARNOVSKY, 1965) and subjected to six series of vacuum $(-600 \mathrm{mmHg})$ for 30 minutes each. After 30 days at $4^{\circ} \mathrm{C}$ the samples were dehydrated by ethyl-alcohol series with increasing concentrations for 15 minutes in each solution from the gradient $(10,20,30,40,50,60,70,80,90$ and $\left.100 \%, \mathrm{v} \mathrm{v}^{-1}\right)$. Then, the samples were immersed in 
hydroxyethyl methacrylate resin (Historesin, Leica ${ }^{\circledR}$, Hildeberg, Germany) and the blocks containing the samples were prepared according to manufacturer's instructions, being stored for 28 days at $24^{\circ} \mathrm{C}$. Blocks containing the samples were sectioned longitudinally or transversely to a thickness of $5 \mu \mathrm{m}$ using an automatic rotary microtome Microm HM 355S (Thermo Scientific). Sections were stained with toluidine blue $\left(0.05 \%, \mathrm{v} \mathrm{v}^{-1}\right)$ in sodium phosphate buffer and citric acid (SAKAI, 1973) for 30 minutes and mounted on slides with Entellan synthetic resin $\left(\right.$ Merck $\left.^{\circledR}\right)$. Histological slides were analyzed and photographed with a light microscope (Opton) and images were captured in micrometric scale.

The experiment was conducted in a completely randomized design in a factorial scheme $(4 \times 5)$, with split-plots subdivided in 4 culture medium preparations (Factor 1 - autoclaved, $0.001 \%$, $0.003 \%$ and $0.005 \% \mathrm{Cl}$ ) and 5 subcultivations (Factor 2 - 0, 28, 49, 70 and 91 days). For this, 4 replicates composed of 5 experimental units were used for each replicate. Each experimental unit was composed of one explant. The data collected from experiment were submitted to Shapiro-Wilk's test $(P<0.05)$ for normal distribution and to Hartley's test $(P<0.05)$ to verify the variance homogeneity among treatments. When necessary, the data were transformed through Box-Cox's test $(P<0.05)$. After, the data were submitted to ANOVA $(P<0.05$ and $P<0.01)$. Duncan's test was performed when significance was detected by ANOVA. Regression equations were estimated for the sub-cultivations periods, selecting the best adjusted model. Histology was characterized by descriptive analysis.

\section{RESULTS AND DISCUSSION}

According to the analysis of variance there was a significant effect for all variables in relation to the effects of culture medium preparation (Factor 1) and sub-cultivations (Factor 2). However, there was no interaction between factors (Factor $1 \times$ Factor 2 ).

The figure $1 \mathrm{~A}$ shows the $C$. regium explants development at each subculture $(28,49,70$ and 91 days) and the formation of callus in the base of the explant, this one being oxidized with the passage of subcultures. Fungal (Figure 1B) and bacterial (Figure 1C) contamination increased during the 91 days but the fungal presence was $15 \%$ major than bacteria from the 49 days and approximately $50 \%$ of the explants presented oxidation signals (Figure 1D). The percentage of callus (Figure 1E) and shoot induction (Figure 1F) has reached approximately
$65 \%$ and $47 \%$, respectively, after 49 days and at the 91 days the survival of the explants decreased $40 \%$ (Figure $1 \mathrm{G}$ ). These data shows the in vitro multiplication viability of $C$. regium as evidenced before (INÁCIO et al., 2011) and allowed to verify that $C$. regium requires several in vitro subcultures to present morphogenic response in relation to the multiplication of shoots, achieving maximum production at 60 days of cultivation.

The use of active chlorine for the chemical sterilization of culture medium aiming to the in vitro propagation of plants has already been proven for several species (RIBEIRO et al., 2011; BRONDANI et al., 2013; NEPOMUCENO et al., 2014); however it was not recorded in literature for $C$. regium. Explants were transferred at each subculture, to the same culture medium composition but with different sterilization preparations such as autoclaving, $0.001 \%, 0.003 \%$, and $0.005 \% \mathrm{Cl}$. After 91 days, the percentage of contamination by fungal was no significant different among the sterilization preparations of culture medium (Figure 2A). However, the contamination by bacterial was significantly controlled by autoclaving, $0.001 \%$ and $0.005 \% \mathrm{Cl}$, while the use of $0.003 \%$ $\mathrm{Cl}$ was significantly the sterilization method less efficient for bacterial proliferation control (Figure $2 \mathrm{~B})$. In the presence of culture medium without active chlorine (i.e., autoclaving method) only $25 \%$ of the explants presented oxidation signals, while with active chlorine the oxidation was at least $30 \%$ higher (Figure 2C). Callus induction in the culture medium with $0.001 \%$ and $0.005 \% \mathrm{Cl}$ was, respectively, $30 \%$ and $20 \%$ major than autoclaving preparation (Figure 2D) while the percentage of shoot induction was no significant different among the sterilization preparations methods (Figure 2E). Finally, 65\% of the explants survived in the presence of culture medium with $0.005 \% \mathrm{Cl}$ after 91 days (Figure $2 \mathrm{~F}$ ). These results indicated that $0.001 \%$ and $0.005 \% \mathrm{Cl}$ satisfactorily controlled the fungal and bacterial multiplication in the culture medium and that the presences of $0.005 \% \mathrm{Cl}$ no affected the C. regium tissue development during 91 days.

The presence of $0.009 \%$ and $0.005 \% \mathrm{Cl}$ in the culture medium for in vitro multiplication of Eucalyptus pellita (TEIXEIRA et al., 2008) and E. benthamii (BRONDANI et al., 2013), respectively, did not affect the shoot viability to the conventional autoclaved preparation. Results also showed that que the presence of $0.005 \% \mathrm{Cl}$ did not affect shoot induction rate in C. regium explants (Figure 2E). These results show a difference among species regarding the most appropriate active chlorine concentration to 


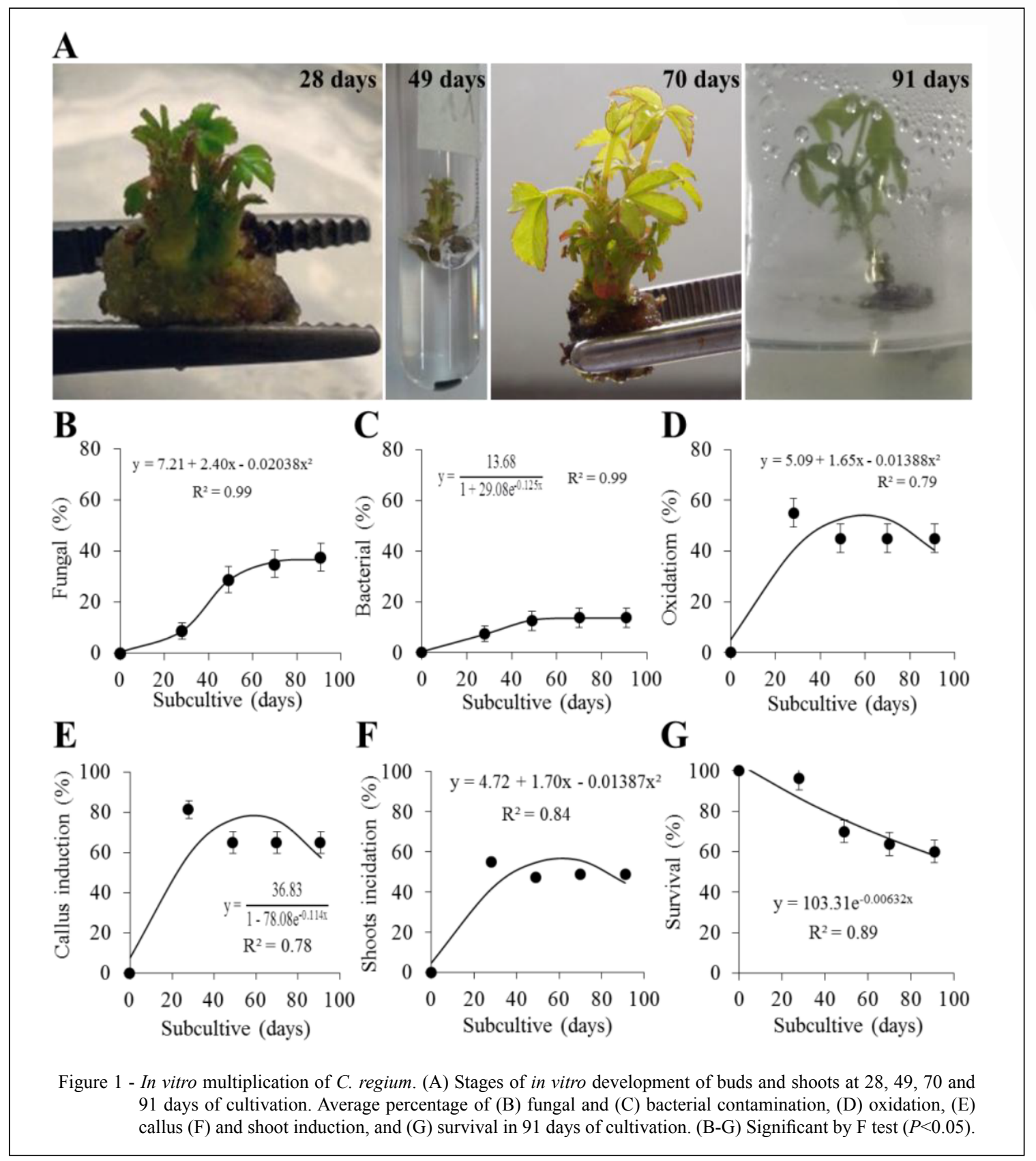

be added to the culture medium, which may be linked to sensitivity to the toxic effects.

As for the oxidation of the explants, results differ from those reported by BRONDANI et al. (2013), which observed oxidation only at concentrations equal to or greater than $0.005 \%$ active chlorine when working with $E$. benthamii, whereas for $C$. regium the oxidation of the explants was detected in all treatments. This fact can be justified by the exudation of endogenous substances by the $C$. regium explants after excision, besides the active chlorine to increase the oxidation of tissues. This behavior was observed for each subculture, especially when it was necessary to perform some cut in the explant. However, there are no studies that identify the nature of exuded substances from $C$. regium explants after excision. An alternative to reduce oxidation would be to avoid unnecessary cuts in the explants, as well as the reduction of subculture time, which according to JONES and SAXENA (2013) may contribute to the reduction of tissue oxidation. 


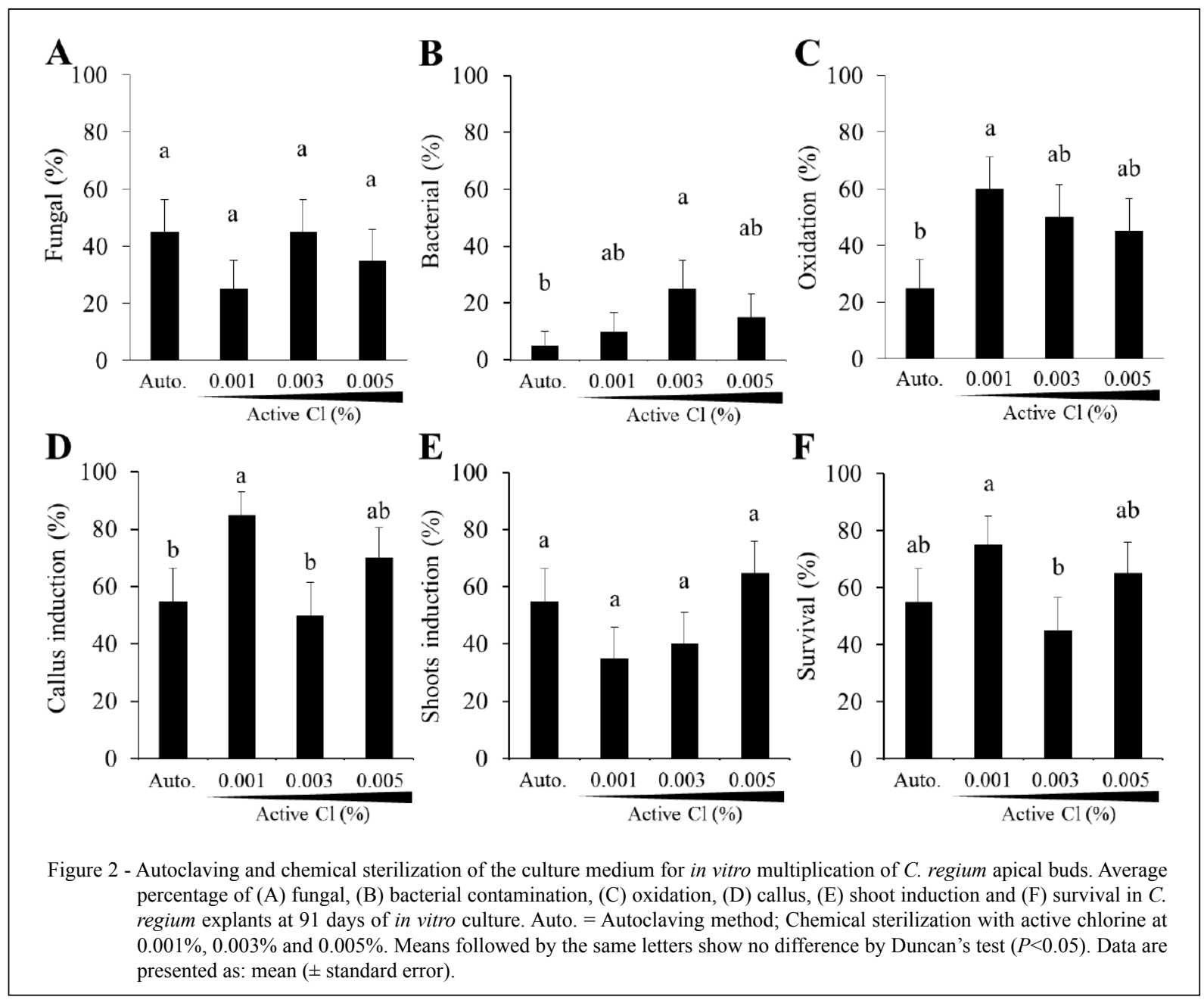

To verify whether the active chlorine would be affecting the occurrence of morphogenic events, histological analysis from explants of $C$. regium in vitro grown at 91 days were performed. Histological analysis showed the presence of small and isodiametric cells in the callus formed indicating areas with intense meristematic activity (Figure 3A). There is presence of unipolar meristematic centers in phase of differentiation (Figure 3B and 3C) and potentially embryonic cells, with asymmetric divisions, similar to that reported in pro-embryonic structures (Figure 3D). The presence of meristematic zones presupposes the formation of adventitious buds and the presence of cells with pro-embryonic characteristics shows the possibility of the occurrence of somatic embryogenesis, which originates from somatic cells, without the occurrence of gametes fusion (CARNEIRO et al., 2014), being an excellent alternative for the asexual propagation and even for the development of synthetic seeds. Thus, these histological results indicate that the active chlorine did not have any deleterious effects on morphogenic events.

According results, the active chlorine supplemented to the culture medium up at concentration of $0.001 \%-0.005 \%$ was feasible for the in vitro multiplication of $C$. regium, when compared with the autoclaving method. Moreover, the chemical sterilization of culture medium demonstrated adequate control of fungal and bacterial contamination, positive response to calogenesis, shoot induction and up to $75 \%$ explants survival. Thus, the possibility of chemical sterilization of culture medium with active chlorine was feasible for the in vitro multiplication of $C$. regium, becoming an alternative to autoclaving method. 


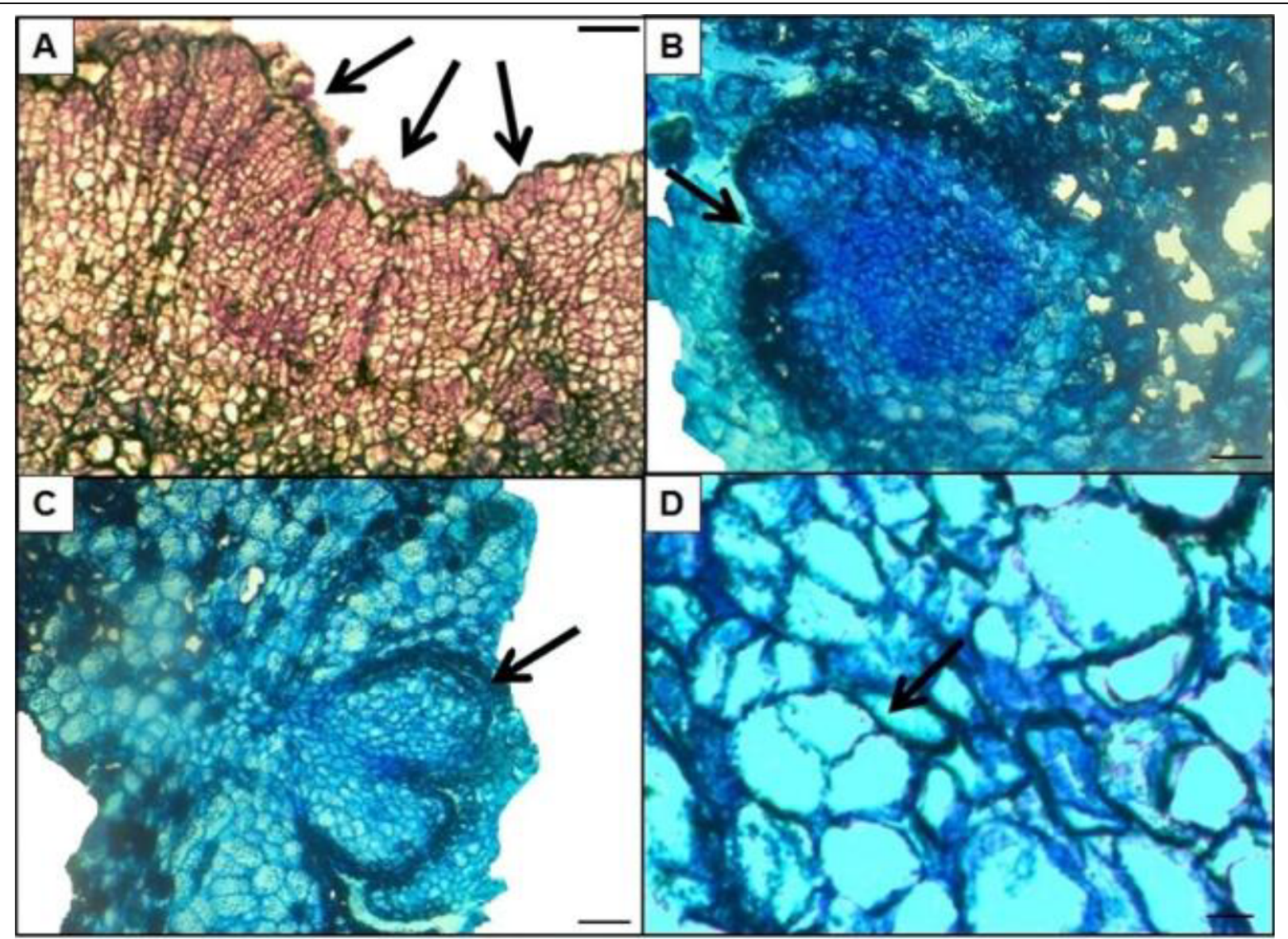

Figure 3 - Histological sections from callus of $C$. regium at 91 days in presence of active chlorine $(0.005 \%)$. The arrows indicate the (A) meristematic zones; (B-C) detail of meristematic centers in differentiation phase; (D) and pro-embryonic cell. Bars represent $100 \mu \mathrm{m}$ in $\mathrm{A}, \mathrm{B}$ and $\mathrm{C}$; and $50 \mu \mathrm{m}$ in $\mathrm{D}$.

\section{CONCLUSION}

The chemical sterilization of culture medium by use of active chlorine at $0.001 \%-0.005 \%$ was efficient for in vitro multiplication of $C$. regium, obtaining similar results to autoclaving method.

\section{ACKNOWLEDGMENTS}

We thank Dra ${ }^{\mathrm{a}}$. Erika Mendes Graner for the descriptive assistance regarding the interpretation of the histological data; Chico Mendes Institute for Biodiversity Conservation (ICMBio) for the authorization to biological material collection (Authorization $\mathrm{N}^{\circ}$. 46295); and Conselho Nacional de Desenvolvimento Científico e Tecnológico (CNPq) (Furlan, F.C.), Coordenação de Aperfeiçoamento de Pessoal de Nível Superior (CAPES) (Gavilan, N.H.; Oliveira, L.S.) and PAEC OEA/GCUB (Zorz, A.Z.) for the scholarship.

\section{CONFLICTS OF INTEREST}

The authors declare no conflict of interest. The founding sponsors had no role in the design of the study; in the collection, analyses, or interpretation of data; in the writing of the manuscript, and in the decision to publish the results.

\section{REFERENCES}

BATISTA, P.F. et al. Overcoming dormancy and characterization of germination in Cerrado 'algodãozinho'seeds treated with dimethyl sulphoxide. South African Journal of Botany, v.92, p.89-93, 2014

BRONDANI, G.E. et al. Chemical sterilization of culture medium: a low cost alternative to in vitro establishment of plants. Scientia Forestalis, v.41, p.257-264, 2013.

BRUM, R.L. et al. Antibacterial activity of Cochlospermum regium essential oil. Fitoterapia, v.68, p.79, 1997.

CAMILLO, J. et al. In vitro conservation of Cochlospermum regium (Schrank) Pilg.- Cochlospermaceae under minimal growth storage. Revista Brasileira de Plantas Medicinais, v.11, p.184-189, 2009.

CARAMORI, S.S. et al. Biochemical characterization of selected plant species from Brazilian Savannas. Brazilian Archives of Biology and Technology, v.47, p.253-259, 2004. 
CARNEIRO, F.S. et al. Somatic embryogenesis in Agave sisalana Perrine: induction, anatomical characterization and regeneration. Pesquisa Agropecuária Tropical, v.44, p.294-303, 2014.

DEEIN, W. et al. In vitro culture medium sterilization by chemicals and essential oils without autoclaving and growth of Chrysanthemum nodes. Journal of Biological, Biomolecular, Agricultural, Food and Biotechnological Engineering, v.7, p.407-410, 2013.

INÁCIO, M.C. et al. In vitro seeds germination and ex vitro plants development of algodãozinho-do-campo. Ciência Rural, v.40, p.2294-2300, 2010

INÁCIO, M.C. et al. In vitro conservation and low cost micropropagation of Cochlospermum regium (Mart. Ex. Scharank). Journal of Medicinal Plants Research, v.5, p.4999-5007, 2011.

INÁCIO, M.C. et al. Histochemical investigation of Cochlospermum regium (Schrank) Pilg. leaves and chemical composition of its essential oil. Natural Product Research, v.28, p.727-731, 2014

JONES, A.M.; SAXENA, P.K. Inhibition of phenylpropanoid biosynthesis in Artemisia annua L.: a novel approach to reduce oxidative browning in plant tissue culture. Plos One, v.8, p.1-13, 2013.

KARNOVSKY, M. J. A formaldehyde-glutaraldehyde fixative of high osmolality for use in electron microscopy. Journal of Cell Biology, v.27, p.137-138, 1965.

MACEK, T. et al. Diethylpyrocarbonate - an effective agent for the sterilization of different types of nutrient media. Plant Cell, Tissue and Organ Culture, v.43, p.1985-190, 1995.

MELO, J.G. et al. Medicinal plants used as antitumor agents in Brazil: an ethnobotanical approach. Evidence-based complementary and alternative medicine, v.2011, Article ID 365359, 14 pages, 2011.

MOREIRA, D.L.; GUARIM-NETO, G. Usos múltiplos de plantas do cerrado: um estudo etnobotânico na comunidade sítio Pindura,
Rosário Oeste, Mato Grosso, Brasil. Polibotânica, v.27, p.159190, 2009.

MURASHIGE, T.; SKOOG, F. A revised medium for rapid growth and bioassays with tobacco tissue cultures. Physiologia Plantarum, v.15, p.473-497, 1962.

MYERS, N. et al. Biodiversity hotspots for conservation priorities. Nature, v.403, p.853-858, 2000.

NEPOMUCENO, C.F. et al. In vitro germination of Hyptis leucocephala Mart. Ex Benth. and Hyptis platanifolia Mart. Ex Benth. Revista Brasileira de Plantas Medicinais, v.16, p.886-895, 2014.

RIBEIRO, J.M. et al. In vitro culture of Sequoia sempervirens L. in nutrient medium sterilized with sodium hypochlorite. Ciência Florestal, v.21, p.77-82, 2011

SAKAI, W.S. Simple method for differential staining of parafilm embedded plant material using toluidine blue. Stain Technology, v.48, p.247-249, 1973.

SÓLON, S. et al. Genus Cochlospermum Kunth with emphasis on ethnobotanic, pharmacological, toxicological, and chemical aspects of the Cochlospermum regium (Mart. Et. Schr.) Pilger. Revista Eletrônica de Farmácia, v.6, p.1-22, 2009.

SÓLON, S. et al. Phenolic derivatives and other chemical compounds from Cochlospermum regium. Química Nova, v.35, p.1169-1172, 2012 .

SOUZA, C.D.; FELFILLI, J.M. The utilization of medicinal plants in the region of Alto Paraíso of Goiás, GO, Brazil. Acta Botanica Brasilica, v.20, p.135-142, 2006.

TEIXEIRA, S. L. et al. Use of sodium hypochlorite in the sterilization of culture medium for in vitro multiplication of Eucalyptus pellita $\mathrm{L}$. Ciência Florestal, Santa Maria, v. 18, n. 2, p. 185-191, 2008.

TRESVENZOL, L.M. et al. Study about informal trade of medicinal plants on Goiânia and neighboring cities, Brazil. Revista Eletrônica de Farmácia, v.3, p.23-28, 2006. 